Економічні науки: збірник наукових прачь Луиького національного технічного університету. Серія "Регіональна економіка". Випуск 17 (67). Редкол.: відп. ред. к.е.н., професор І.В. Кривов’язюк. Луцьк: ІВВ Луцького НТУ, 2020. 348 с.

УДК 332:330.322

Бандура Тетяна

ДУ «Інститут регіональних досліджень ім. М.І. Долішнього $\mathrm{HAHУ»}$

\title{
ІНСТИТУЦІЙНЕ ЗАБЕЗПЕЧЕННЯ ІНВЕСТИЦІЙНОЇ ДІЯЛЬНОСТІ КАРПАТСЬКОГО РЕГІОНУ
}

У статті розглянуто інституційне забезпечення інвестиційної діяльності чотирьох прикордонних областей Карпатського регіону. Проаналізовано доступність та наявність інформації для інвесторів на сайтах державних обласних адміністрацій: Львівської, Закарпатської, Івано-Франківської, Чернівецької. На основі світового досвіду залучення інвестицій у регіони запропоновано створення агенції залучення інвестицій Карпатського регіону 3 представництвами у кожній 3 областей 3 функцією «єдиного вікна» та супроводом інвестора та інтернет-платформи для відображення інвестиційних пропозицій регіону.

Ключові слова: інституційне забезпечення, агенції залучення інвестицій, Карпатський регіон, служба інвестора, інвестиційний потенціал, нарощення інвестиційного потенціалу.

\section{Bandura T. \\ INSTITUTIONAL MAINTENANCE OF THE INVESTMENT ACTIVITY IN THE CARPATHIAN REGION}

The paper examines the institutional maintenance of the investment activity in four border oblasts of the Carpathian Region. The accesibility and availability of information for investors on the websites of Livska, Zakarpatska, Ivano-Frankivska, and Chernivetska State Public Administrations are analyzed. Based on the foreign experience of attracting investment to the regions, the paper suggests creating an Investment Attraction Agency for the Carpathian Region with representative divisions in each oblast that would operate as "single windows" and provide maintenance for the investors. The article dwells on the issue of foreign investment attraction to regions. The importance of foreign investment in regions' economy and the country in general is emphasized, the factors, which are decisive for investors in the analysis of region's attractiveness, and factors that influence the level of to regions are examined, the mechanisms of foreign direct investment attraction are analyzed through the prism of cross-border cooperation forms.

Key words: institutional maintenance, investment attraction agencies, Carpathian region, investor service. 

університету. Серія "Регіональна економіка". Випуск 17 (67). Редкол.: відп. ред. к.е.н., професор І.В. Кривов’язюк. Луцьк: ІВВ Луцького НТУ, 2020. 348 с.

Бандура Т.

\section{ИНСТИТУЦИОНАЛЬНОЕ ОБЕСПЕЧЕНИЕ ИНВЕСТИЦИОННОЙ ДЕЯТЕЛЬНОСТИ КАРПАТСКОГО РЕГИОНА}

В статье рассмотрены институциональное обеспечение инвестиционной деятельности четырех приграничных областей Карпатского региона. Проанализированы доступность и наличие информации для инвесторов на сайтах государственных областных администраций: Львовской, Закарпатской, Ивано-Франковской, Черновицкой. Проанализированы пути наращивания инвестиционного потенциала. Исследована роль агентств территориального развития в инвестиционной деятельности региона, и объяснено, каким образом они должны работать и какие ресурсы необходимы для этого. Даны практические рекомендации по улучшению привлекательности региона для иностранных инвесторов. На основе мирового опыта привлечения инвестиций в регионы предложено создание агентства привлечения инвестиций Карпатского региона с представительствами в каждой из областей с функцией «единого окна» и сопровождением инвестора и интернет-платформы для отображения инвестиционных предложений региона.

Ключевые слова: институциональное обеспечение, агентства привлечения инвестиций, Карпатский регион, служба инвестора, инвестиционный потенциал, наращивание инвестиционного потенциала.

\section{Постановка проблеми у загальному вигляді та її зв'язок 3 важливими науковими та практичними} завданнями. Одним 3 пріоритетів державної регіональної економічної політики сьогодні $є$ забезпечення сталого розвитку регіонів. Світові тенденції розвитку інвестиційної діяльності демонструють взаємозалежність залучених інвестицій у економіку та з покращенням рівня добробуту регіону.

Залучені інвестиції у регіони допоможуть розвивати підприємництво та створювати нові робочі місця, і як наслідок сприятимуть збільшенню обсягу податкових відрахувань, які будуть спрямовані на фінансування соціально-економічного розвитку, удосконалення інфраструктури, диверсифікації галузевої структури економіки тощо.

Аналіз останніх досліджень, у яких започатковано вирішення проблеми дозволить удосконалити інституційне 
Економічні науки: збірник наукових прачь Луиького національного технічного університету. Серія "Регіональна економіка". Випуск 17 (67). Редкол.: відп. ред. к.е.н., професор І.В. Кривов'язюк. Луиьк: ІВВ Луцького НТУ, 2020. 348 с.

забезпечення інвестиційної діяльності Карпатського регіону. Досліджуючи доступність інформації для інвесторів у країнах Європейського Союзу, бачимо, що вона $є$ і може надаватися АПІ (агенції просування інвестицій), які активно працюють у відповідних регіонах. Слід зазначити, що співпраця 3 інвестором здійснюється виключно через АПІ шляхом «єдиного вікна» та обслуговуванням їх протягом усього періоду перебування на ринку регіону та вирішення будь-яких питань, щодо проблем ведення бізнесу.

Цілі статті полягають у пошуку шляхів нарощення інвестицій у Карпатському регіоні.

Виклад основного матеріалу дослідження 3 повним обгрунтуванням отриманих наукових результатів. На сьогодні залученням інвесторів у Карпатському регіоні та співпрацею з ними займаються відповідні підрозділи обласних державних адміністрацій, міських рад та «Укрінвест» у західному регіоні (практично єдина функціональна, діюча агенція у Карпатському регіоні). Але, на жаль, не у всіх областей ці підрозділи активно відображають інформацію через інтернет-ресурси. В сучасну епоху інформаційних технологій $\epsilon$ перевагою вільний доступ до потрібної інформації 3 мережі інтернет. Якщо дана інформація не відображається через пошукові системи або іiі складно знайти - вона апріорі не буде опрацьована і розглянута зацікавленою стороною.

У Львівській обласній державній адміністрації (ЛОДА) при департаменті економічної політики створений відділ 3 залучення інвестицій [1]. Основними його завданнями $\epsilon$ залучення інвестицій та супровід інвестиційних проектів. На веб-сайті ЛОДА є доступна така інформація для інвесторів, як:

-інвестиційні об'єкти на території Львівської області;

-пропозиції земельних ділянок типу greenfields для створення індустріальних парків на території Львівської області;

-об'єкти незавершеного будівництва, що можуть бути задіяні під виробничі приміщення;

-подача greenfields та brownfields на порталі державних послуг iGov; 
Економічні науки: збірник наукових прачь Луиького національного технічного університету. Серія "Регіональна економіка". Випуск 17 (67). Редкол.: відп. ред. к.е.н., професор І.В. Кривов'язюк. Луиьк: ІВВ Луцького НТУ, 2020. 348 с.

-інвестиційний паспорт Львівської області.

Також розміщена інформація для різних цільових аудиторій згідно «Стратегії розвитку Львівщини на період до 2027 року», «Стратегії розвитку Львівщини на період до 2020 року»; реалізація Стратегії розвитку Львівської області; існуючі обласні програми та їх інфографіка за певний період.

При ЛОДА створений орган «Служба інвестора», у функції якого входить задоволення потреб та вирішення проблем інвесторів.

«Служба інвестора - це постійно діючий консультативнодорадчий орган при обласній державній адміністрації, який створюється 3 метою сприяння вирішенню поточних проблемних питань наявних та потенційних інвесторів у процесі здійснення ними господарської діяльності на території Львівської області» [2].

У Івано-Франківській області на веб-сайті обласної державної адміністрації наявна інформація про департамент економічного розвитку, промисловості та інфраструктури. Окремого підрозділу з інвестиційної політики у області немає, але $є$ створене управління інвестиційної політики виконавчого комітету Івано-Франківської міської ради, яке $є$ підзвітним та підконтрольним міській раді, підпорядковується ÏÏ виконавчому комітету [3].

Основними завданнями управління інвестиційної політики виконавчого комітету Івано-Франківської міської ради є:

-координація роботи по залученню інвестицій та здійсненню капіталовкладень, супроводження інвестиційних проектів;

-формування позитивного інвестиційного іміджу міста та просування його інвестиційних можливостей;

-участь у проектах міжнародної технічної допомоги;

-координація грантової діяльності виконавчих органів міської ради.

У Закарпатській області на веб-сайті $є$ інформація про управління зовнішньоекономічних зв’язків, інвестицій та транскордонного співробітництва. 
Економічні науки: збірник наукових прачь Луиького національного технічного університету. Серія "Регіональна економіка". Випуск 17 (67). Редкол.: відп. ред. к.е.н., професор І.В. Кривов'язюк. Луиьк: ІВВ Луцького НТУ, 2020. 348 с.

Управління зовнішньоекономічних зв'язків, інвестицій та транскордонного співробітництва облдержадміністрації здійснює координацію діяльності у сфері зовнішньоекономічної діяльності, інвестиційної діяльності та транскордонного співробітництва, з метою найбільш ефективного використання потенціалу для потреб соціально-економічного розвитку області [4].

На веб-сайті Закарпатської ОДА розміщена карта за 2018 рік - Інвестиційні проекти, де є нанесені за попередній рік об'єкти та розмір вкладених капітальних та іноземних інвестицій [5].

У Чернівецькій ОДА у структурі немає окремого відділу, який би займався інвестиційною політикою області. У завдання департаменту регіонального розвитку входить реалізація державної політики у сферах зовнішньоекономічної та інвестиційної діяльності. Будь-яка інформація у сфері інвестиційної діяльності на веб-сайті відсутня.

Розроблена інвестиційна стратегія області, наявність діючих інституцій, які активно працюють та відображають відповідну інформацію через онлайн-ресурси дають відповідні результати з залучення інвестицій.

Важливим є відображення інформації для інвесторів на сайтах обласних державних адміністрацій та наявність контактів відповідних підрозділів. 3 проведеного порівняльного аналізу інформаційного наповнення на веб-сайтах ОДА Карпатського регіону видно, що лише Львівська область надає інформацію щодо інвестування у вільному доступі для користувачів. Можемо провести паралелі між наявністю та доступністю інформації, яка стосується інвестиційної політики регіону та кількістю реалізованих інвестиційних проектів, де Львівська область є лідером.

Доцільність створення інвестиційних платформ в регіоні, де би відображалась інформація, актуальна для потенційних інвесторів та територіальних громад щодо вільних зелених та коричневих зон в регіоні, індустріальних парків, наявних 
Економічні науки: збірник наукових прачь Луиького національного технічного університету. Серія "Регіональна економіка". Випуск 17 (67). Редкол.: відп. ред. к.е.н., професор І.В. Кривов’язюк. Луцьк: ІВВ Луцького НТУ, 2020. 348 с.

інвестиційних ресурсів, контактів для зворотнього зв’язку, є беззаперечною.

Таблиця 1

Порівняльний наліз інформаційного наповнення веб-сайтів обласних державних адміністрацій Карпатського регіону

\begin{tabular}{|c|c|c|c|c|}
\hline Критерії & $\begin{array}{c}\text { Івано- } \\
\text { Франківська }\end{array}$ & Закарпатська & Львівська & Чернівецька \\
\hline $\begin{array}{l}\text { Наявність } \\
\text { підрозділу, } \\
\text { який } \\
\text { займається } \\
\text { інвестиційною } \\
\text { політикою } \\
\text { області }\end{array}$ & $\begin{array}{l}\text { Управління } \\
\text { інвестиційної } \\
\text { політики } \\
\text { виконавчого } \\
\text { комітету Івано- } \\
\text { Франківської } \\
\text { міської ради }\end{array}$ & $\begin{array}{l}\text { Управління } \\
\text { зовнішньоеко- } \\
\text { номічних } \\
\text { зв'язків, } \\
\text { інвестицій та } \\
\text { транскордонного } \\
\text { співробітництва }\end{array}$ & $\begin{array}{l}\text { Департамент } \\
\text { економічної } \\
\text { політики: } \\
\text { відділ } \\
\text { залучення } \\
\text { інвестицій }\end{array}$ & $\begin{array}{l}\text { Департамент } \\
\text { регіонально- } \\
\text { го розвитку }\end{array}$ \\
\hline $\begin{array}{l}\text { Інвестиційний } \\
\text { паспорт }\end{array}$ & 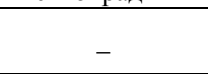 & - & + & - \\
\hline $\begin{array}{l}\text { Інвестиційні } \\
\text { об'єкти }\end{array}$ & - & + & + & - \\
\hline $\begin{array}{l}\text { Заходи, } \\
\text { спрямовані на } \\
\text { залучення } \\
\text { інвесторів }\end{array}$ & - & + & + & - \\
\hline $\begin{array}{l}\text { Інформація про } \\
\text { інвестиційні } \\
\text { проекти } \\
\end{array}$ & - & - & + & - \\
\hline $\begin{array}{l}\text { Контактна } \\
\text { інформація }\end{array}$ & + & + & + & + \\
\hline
\end{tabular}

Джерело: розроблено автором на основі аналізу сайтів обласних державних адміністрацій Львівської, Закарпатської, Івно-Франківської та Чернівецької областей $[1,2,3,4]$.

Об'єднані територіальні громади також повинні розміщувати на власних веб-сайтах інформацію про наявні інвестиційні ресурси на їхній території та сформовані пропозиції для інвесторів.

Такі платформи в світі уже існують, активно створюються та просуваються. Прикладом є GetMarket. У червні 2019 року Dentons, CMS Cameron McKenna Nabarro Olswang, Everlegal, Baker Tilly, IKHЕТ підписали Меморандум про співпрацю та анонсували створення відкритої онлайн-платформи для зелених проектів - GetMarket [6]. 
Економічні науки: збірник наукових прачь Луиького національного технічного університету. Серія "Регіональна економіка". Випуск 17 (67). Редкол.: відп. ред. к.е.н., професор І.В. Кривов’язюк. Луцьк: ІВВ Луцького НТУ, 2020. 348 с.

Головна мета платформи GetMarket - різнобічна підтримка компаній, які є гравцями цього ринку.

Також в Україні створений сайт

біржі інвестиційних проектів STARTUP NETWORK, яка пропонує на своїй платформі інвестувати в цікаві стартапи, знайти інвестиції для свого бізнесу, розмістити проекти та ідеї для бізнесу для пошуку фінансування [7].

Як бачимо інформація для інвесторів $\epsilon$, але вона концентрується на різних інтернет ресурсах. Для пошуку інвестиційних пропозицій потрібно витратити багато часу, а ймовірність, що не усі пропозиції будуть розглянуті та проаналізовані також присутня. Доцільно було б створення єдиної інвестиційної платформи Карпатського регіону, де ця інформація би акумулювалась. Обласні державні адміністрації, міські ради, об'єднані територіальні громади надавали б інформацію 3 активним посиланням на власні ресурси. На сьогодні інвестиційна інтернет-платформа має можливість стати затребуваним i необхідним ресурсом, який надасть вільний доступ до інформації та допоможе залученню інвесторів у Карпатський регіон.

Висновки. Створення єдиної агенції 3 залучення інвестицій у Карпатський регіон та інвестиційної платформи як потужного інформаційного ресурсу території, допоможе вирішити проблему неповноти та відсутності достовірного джерела інформації для потенційних інвесторів.

\section{Список бібліографічного опису}

1.Департамент кономічної політики ЛОДА https://loda.gov.ua/investyciyna_diyal_nist

2.Львівська обласна адміністрація, https://loda.gov.ua/upload/users_files/22/upload/Polozhennya\%20pro\%20Sluzhbu\% 20investora.pdf

3.Управління інвестиційної політики м. Івано-Франківськ http://www.mvk.if.ua/uprinvest

4. Закарпатська обласна державна адміністрація, https://carpathia.gov.ua/storinka/informaciya-pro-upravlinnya-zovnis, noekonomichnyh-zvyazkiv-investyciy-ta-transkordonnogo 
Економічні науки: збірник наукових прачь Луиького національного технічного університету. Серія "Регіональна економіка". Випуск 17 (67). Редкол.: відп. ред. к.е.н., професор І.В. Кривов’язюк. Луцьк: ІВВ Луцького НТУ, 2020. 348 с.

5.Інвестиційна карта Закарпатської ОДА https://www.google.com/maps/d/viewer?mid=17sMrWvup3sfWrhZQ4a5w8PesMU $\underline{\mathrm{sbCgI} \& l 1=49.062501908149855 \% 2 \mathrm{C} 24.363002864487157 \& \mathrm{z}=9}$

6.Онлайн-платформа для зелених проектів GetMarket https://getmarket.com.ua/

7.Сайт біржі інвестиційних проектів STARTUP NETWORK https://startup.ua/

\section{References}

1.Departament ekonomichnoi polityky LODA https://loda.gov.ua/investyciyna_diyal_nist_

2.Lvivska oblasna administratsiia, https://loda.gov.ua/upload/users_files/22/upload/Polozhennya\%20pro\%20Sluzhbu\% 20investora.pdf

3.Upravlinnia investytsiinoi polityky m. Ivano-Frankivsk http://www.mvk.if.ua/uprinvest

4. Zakarpatska oblasna derzhavna administratsiia, https://carpathia.gov.ua/storinka/informaciya-pro-upravlinnya-zovnis, noekonomichnyh-zvyazkiv-investyciy-ta-transkordonnogo

5.Investytsiina karta Zakarpatskoi ODA https://www.google.com/maps/d/viewer?mid=17sMrWvup3sfWrhZQ4a5w8PesMU sbCgI\&ll=49.062501908149855\%2C24.363002864487157\&z=9

6.Onlain-platforma dlia zelenykh proektiv GetMarket https://getmarket.com.ua/

7.Sait birzhi investytsiinykh proektiv STARTUP NETWORK https://startup.ua/ 